\title{
Perhitungan Waktu Standar Pelayanan Kasir Minimarket X Di Kota Dumai
}

\author{
Fitra $^{1}$ \\ 1)Program Studi Teknik Industri, Sekolah Tinggi Teknologi Dumai \\ Jl. Utama Karya Bukit Batrem II \\ Email: famukhtyfitra@gmail.com
}

\begin{abstract}
ABSTRAK
Minimarket merupakan toko yang menjual segala macam barang dan makan yang menerapkan sistem mesin kasir poin sale. Minimarket $\mathrm{X}$ mempekerjakan 8 karyawan dengan sistem shift. Empat karyawan pada shift pagi mulai dari jam 07.00-15.00 wib dan 4 orang pada shift sore mulai dari jam 15.00-11.00 wib. Waktu yang dibutuhkan seorang kasir untuk melayani satu konsumen bermacam-macam tergantung dari banyaknya jumlah belanjaan konsumen dan kecepatan karyawan. Dengan waktu tersebut kita tidak dapat menentukan waktu standar dengan menggunakan metode time watch study namun bisa menggunakan metode work sampling dengan melihat aktifitas bekerja dan tidak berkerjanya. Pengumpulan data dilakukan dengan cara observasi melalui pengamatan langsung selama 5 hari. Waktu pengamatan dilakukan untuk karyawan shift pagi berdasarkan waktu yang terpilih menggunakan tabel bilangan acak. Hasil pengujian BKA dan BKB setelah data di perolah tidak ada yang keluar dari batas kontrol yaitu 0,94 untuk batas atas dan 0,70 untuk batas bawah sedangkan hasil uji kecukupan data di dapati data cukup karena nilai $\mathrm{N}$ hitung $<$ dari $\mathrm{N}$ pengamatan yaitu $88<200$. Jumlah konsumen yang dilayani adalah 217 orang. Presentasi produktifitas yang diperoleh adalah $82,00 \%$. Oleh karena itu waktu baku yang diperoleh adalah 12,52 menit dengan nilai faktor penyesuaian 1,16 dan nilai kelonggaran yang diberikan adalah $19 \%$.
\end{abstract}

Kata Kunci: Minimarket, Waktu Standar, Work Sampling.

\begin{abstract}
Minimarket is a store that sells all kinds of goods and food that uses a point sale cash register system. Minimarket $X$ employs 8 employees with a shift system. Four employees on morning shifts starting from 07.00-15.00 WIB and 4 people on afternoon shifts starting from 15.00-11.00 WIB. The time it takes for a cashier to serve one customer varies depending on the amount of consumer purchases and the speed of the employees. With that time, we cannot determine the standard time using the time watch study method, but we can use the work sampling method by looking at work and non-work activities. Data collection was carried out by means of observation through direct observation for 5 days. Time observations were made for morning shift employees based on the time selected using a random number table. The results of the $B K A$ and BKB tests after the data in the processing did not leave the control limit, namely 0.94 for the upper limit and 0.70 for the lower limit, while the results of the data sufficiency test were found to be sufficient because the value of $N$ count <of $N$ observations was $88<200$. The number of consumers served is 217 people. The percentage of productivity obtained is $82.00 \%$. Therefore the standard time obtained is
\end{abstract}


12.52 minutes with an adjustment factor value of 1.16 and the allowance value given is $19 \%$.

Keywords: Minimarket, Standard Time, Work Sampling.

\section{Pendahuluan}

Minimarket merupakan toko yang menjual segala macam barang dan makan yang menerapkan sistem mesin kasir poin sale untuk penjualannya namun tidak selangkap dan sebesar supermarket. Dalam proses pelaksanaannya minimarket menerapkan sistem swalayan, dimana pembeli mengambil sendiri barang yang ia butuhkan dari rak-rak minimarket dan membayarnya dimeja kasir. Minimarket yang ada di Indonesia saat ini ada yang dikelola individu perorang atau yang sering disebut dengan minimarket mandiri dan minimarket berjejaring. Bangunan minimarket berukuran $100 \mathrm{~m}^{2}$ sampai dengan $999 \mathrm{~m}^{2}$. Minimarket sudah banyak berdiri di Kota Dumai yang merupakan salah satu kota yang ada di Provinsi Riau Negara Indonesia. Salah satu minimarket yang ada di Kota Dumai adalah Minimarket X yang sistem kerja dan pengoperasiannya sama seperti minimarket pada umumnya.

Minimarket X mempekerjakan 8 karyawan dengan sistem shift. Shift kerja merupakan pola waktu kerja yang diberikan pada karyawan untuk mengerjakan sesuatu dan biasanya dibagi atas kerja pagi, sore dan malam hari menurut Suma'mur dalam Khalid (2014) dan dalam Fitra (2019). Empat karyawan pada shift pagi mulai dari jam 07.00-15.00 wib dan 4 orang pada shift sore mulai dari jam 15.00-11.00 wib. Keempat karyawan tersebut 2 menjadi kasir dan 2 orang lainnya menjaga kebersihan minimarket dan penyusunan barang namun semua karyawan bisa menjadi kasir saat karyawan yang ditugaskan sedang istirahat dan ada konsumen yang berbelanja.

Waktu yang dibutuhkan untuk seorang kasir untuk melayani satu konsumen itu bermacam-macam tergantung dari banyaknya jumlah belanjaan konsumen dan kecepatan karyawan. Dengan waktu yang bermacam-macam tersebut kita tidak dapat menentukan waktu standar dengan menggunakan metode time watch study namun bisa menggunakan metode work sampling dengan melihat aktifitas bekerja dan tidak berkerjanya seorang karyawan. Metode work sampling telah digunakan dalam menentukan waktu baku karyawan SPBU XYZ di Kota Dumai oleh Fitra, dkk (2020) dimana waktu baku yang diperoleh adalah 2,19 menit. Kasir di Minimarket X ini juga memerlukan waktu yang bermacam-macam untuk menyani konsumen saat pembayaran. Dengan tidak diketahuinya waktu yang standar dalam melayani konsumen maka dilakukan penelitian yang bertujuan untuk mengetahui waktu standar seorang kasir Minimarket $\mathrm{X}$ dalam melayani konsumen dengan menggunakan metode Work Sampling.

Work sampling atau sampling pekerjaan merupakan salah satu pengukuran untuk menentukan waktu standar/waktu baku secara langsung karena dilakukan dengan melakukan pengukuran secara langsung di tempat berjalannya pekerjaan (Sutalaksana, dkk, 2006). Cara kerja sampling pekerjaan berbeda dengan pengukuran jam henti dimana, pengamat tidak terus menerus berada di tempat 
pekerjaan melainkan mengamati (ditempat pekerjaan) hanya pada sesaat-sesaat pada waktu-waktu yang ditentukan secara acak (Sutalaksana, dkk, 2006).

\section{Metode Penelitian}

Pengambilan data pada penelitian ini dilakukan secara langsung melalui observasi atau pengamatan. Pengamatan yang dilakukan terhadap karyawan Minimarket X yang bertugas sebagai kasir. Pengamatan dilakukan selama 5 hari dan waktu pengamatan dilakukan saat karyawan masuk shift pagi. Jam kerja shift pagi dimulai dari jam 07.00 wib sampai dengan jam 15.00 wib dengan jumlah jam kerja 8 jam. Interval waktu pengmatan per 5 menit kerja, sehingga jumlah pengamatan untuk 8 jam kerja adalah 96 pengamatan. karena penelitian ini menggunakan metode work sampling untuk penentuan waktu standarnya maka pengamatan dilakukan sesuai dengan tabel bilangan acak yang terpilih sebanyak 40 pengamatan.

Penelitian ini dilakukan melalui beberapa tahapan yaitu melakukan penelitian pendahuluan untuk mengetahui permasalahan yang terjadi, mengidentifikasi masalah, menetapkan tujuan penelitian, mengumpulkan data, pengolahan data dan kesimpulan. Tahapan yang dilakukan dalam menggunakan work sampling menurut Sutalaksana, dkk (2006) adalah:

a. Melakukan sampling pendahuluan

Disini dilakukan sejumlah kunjungan yang banyaknya ditentukan oleh pengukur, biasanya tidak kurang dari 30.

b. Pengujian keseragaman data

Menentukan batas-batas kontrolnya yaitu batas kontrol atas (BKA) dan batas kontrol bawah (BKB) sebagai berikut:

$$
\begin{aligned}
& B K A=\bar{p}+3 \sqrt{\frac{\bar{p}(1-\bar{p})}{\bar{n}}} \\
& B K B=\bar{p}-3 \sqrt{\frac{\bar{p}(1-\bar{p})}{\bar{n}}}
\end{aligned}
$$

dimana

$\bar{p}=\frac{\sum p_{i}}{k}$

dengan $\mathrm{p}_{\mathrm{i}}$ adalah persentase produktif di hari ke-i dan $\mathrm{k}$ adalah jumlah hari pengamatan.

$\bar{n}=\frac{\sum n_{i}}{k}$

Dengan $\mathrm{n}_{\mathrm{i}}$ adalah jumlah pengamatan yang dilakukan pada hari ke-i.

c. Menghitung jumlah pengamatan yang di perlukan

Jumlah pengamatan yang diperlukan untuk tingkat keyakinan 5\% dan tingkat keyakinan 95\% diketahui melalui rumus: 
$N^{\prime}=\frac{k s_{s}^{2}(1-\bar{p})}{\bar{p}}$

atau

$N^{\prime}=\frac{1600(1-\bar{p})}{\bar{p}}$

d. Menentukan waktu pengamatan secara acak

Untuk satu hari kerja dibagi kedalam satuan-satuan waktu yang besarnya ditentukan oleh pengukur. Biasanya panjang satu-satuan waktu tidak terlampau singkat dan juga tidak terlampau panjang. Berdasarkan satuan-satuan waktu inilah saat-saat kunjungan ditentukan (Sutalaksana, dkk, 2006). Sutalaksana, dkk (2006) menyatakan bahwa tabel bilangan acak biasanya terdapat pada bukubuku statistik ataupun buku-buku khusus teknik. Tabel bilangan acak yang digunakan pada penelitian ini dapat dilihat pada Tabel 1.

Tabel 1. Bilangan Acak yang Digunakan

\begin{tabular}{|c|c|c|c|c|c|c|c|c|c|}
\hline 39 & 65 & 76 & 45 & 45 & 19 & 90 & 69 & 64 & 61 \\
\hline 20 & 26 & 36 & 34 & 62 & 58 & 24 & 97 & 14 & 97 \\
\hline 95 & 4 & 70 & 99 & 9 & 73 & 71 & 23 & 70 & 90 \\
\hline 65 & 97 & 60 & 12 & 11 & 31 & 56 & 34 & 19 & 19 \\
\hline 47 & 83 & 75 & 51 & 33 & 30 & 61 & 38 & 20 & 46 \\
\hline 72 & 20 & 47 & 33 & 84 & 51 & 67 & 47 & 97 & 19 \\
\hline
\end{tabular}

e. Menentukan Waktu Standar/Waktu Baku

Waktu baku dihitung dengan menerapkan faktor penyesuaian untuk menentukan waktu normal. Setelah waktu normal diperoleh kemudian diberikan kelonggaran sehingga diperoleh waktu standar/waktu baku.

\section{Hasil Dan Pembahasan}

Pengumpulan data dilakukan dengan cara observasi melalui pengamatan langsung karyawan kasir minimarket X selama 5 hari. Waktu pengamatan dilakukan mulai dari jam 07.00 wib sampai dengan jam 15.00 wib berdasarkan waktu yang terpilih menggunakan tabel bilangan acak pada Tabel 1. Hasil pengamatan selama 5 hari dapat dilihat pada Tabel 2 .

Tabel 2. Hasil Pengamatan Selama 5 Hari

\begin{tabular}{|c|c|c|c|c|c|c|}
\hline \multirow{2}{*}{ Kegiatan } & \multicolumn{5}{|c|}{ Frekuensi Teramati Pada Hari ke } & \multirow{2}{*}{ Jumlah } \\
\hline & 1 & 2 & 3 & 4 & 5 & \\
\hline Bekerja & 33 & 32 & 32 & 31 & 36 & 164 \\
\hline Tidak Bekerja & 7 & 8 & 8 & 9 & 4 & 36 \\
\hline
\end{tabular}




\begin{tabular}{|l|r|r|r|r|r|r|}
\hline Jumlah & 40 & 40 & 40 & 40 & 40 & 200 \\
\hline \% Produktivitas & 82,5 & 80 & 80 & 77,5 & 90 & 82 \\
\hline \% Non-produktivitas & 17,5 & 20 & 20 & 22,5 & 10 & 18 \\
\hline Jumlah Konsumen & 55 & 35 & 41 & 48 & 38 & 217 \\
\hline
\end{tabular}

Berdasarkan Tabel 2 dapat dihitung batas-batas kontrolnya. Dari jumlah rata-rata data maka didapatlah p dibawah ini dengan Rumus 3.

$\overline{\mathrm{p}}=\frac{82,5+80+80+77,5+90}{5}: 100=\frac{410}{5}: 100=0,82$

Dengan $\mathrm{n}$ adalah jumlah pengamatan yang dilakukan pada hari ke-i maka didapatlah $\mathrm{n}$ di bawah dengan merujuk pada Rumus 4 .

$\bar{n}=\frac{40+40+40+40+40}{5}=\frac{200}{5}=40$

Sehingga dapat ditentukan batas-batas kontrolnya dengan tingkat keyakinan 95\% dan ketelitian 10\%. Untuk menentukan keseragaman data operator dapat dilihat di bawah ini berdasarkan Rumus 1 dan Rumus 2 .

$\mathrm{BKA}=0,82+\left(2 \frac{\sqrt{0,82(1-0,82)}}{40}\right)=0,94$

$\mathrm{BKB}=0,82-\left(2 \frac{\sqrt{0,82(1-0,82)}}{40}\right)=0,70$ menit

Selanjutnya menentukan jumlah pengamatan yang diperlukan untuk tingkat ketelitian $10 \%(\mathrm{~s}=0,1 \%)$ dari tingkat keyakinan $95 \%(\mathrm{k}=2)$ dan $\mathrm{N}$ berjumlah 200 dapat dihitung dengan menggunakan Rumus 5.

$\mathrm{N}^{\prime}=\frac{400(1-0,82)}{0,82}=88$

Karena N'< N yaitu $88<200$ maka data pengamatan yang dapat diambil sudah cukup, maka dari itu untuk tingkat ketelitian dan keyakinan sudah memenuhi dan pengukuran telah dianggap selesai.

Setelah menentukan BKA, BKB dan Jumlah Pengamatan maka langah selanjutnya menentukan waktu baku. Data pengamatan yang dilakukan 200 kali selama 5 hari penuh dalam kegiatan kerja dengan frekuensi kegiatan produktif yang teramati adalah 164 dan jumlah konsumen yang terlayani selama dilakukan sampling kerja adalah 217 maka:
a. Jumlah pengamatan
: 200 kali.
Jumlah produktif
$: 164$.
Presentase produktif
$: 164 / 200 \times 100 \%=82,00 \%$.

b. Jumlah menit pengamatan : 5 hari x 8 jam x 60 menit $=2400$ menit.

Jumlah menit produktif $\quad:(82,00 / 100) \times 2400=1.968$ menit. 
c. Jumlah barang di produksi : 217 Konsumen.

Waktu diperlukan/kend araan : 1.968/217 $=9,07$ menit.

d. Faktor penyesuaian yang digunakan menurut Westinghause adalah

Keterampilan : Excellent (B2) $+0,08$

Usaha $\quad:$ Good $(\mathrm{C} 1) \quad+0,05$

Kondisi Kerja $\quad: \operatorname{Good}(\mathrm{C}) \quad+0,02$

Konsistensi $\quad:$ Good $(\mathrm{C}) \quad+0,01$

Jumlah $\quad+0,16$

Maka dihasilkan $\mathrm{p}=(1+0,16)$ atau $\mathrm{p}=1,16$

sehingga waktu normalnya adalah

$\mathrm{Wn}=9,07 \times 1,16=10,52$ menit

e. Kelonggaran yang ditentukan berdasarkan hasil pengamatan adalah

$\begin{array}{ll}\text { Tenaga yang dikeluarkan (sangat ringan):Memegang mesin kasir } & 7\end{array}$

Sikap kerja (berdiri diatas dua kaki): Berdiri 2

Gerakan kerja (normal): Tidak ada beban 0

Kelelahan mata (pandangan konsentrasi): Pencahayaan baik $\quad 7$

Keadaan suhu (normal): Kelelahan normal 0

Keadaan afmosfer (baik): Ruang yang berventilasi baik, udara segar $\quad 0$

Keadaan lingkungan yang baik: Bersih, sehat, cerah 0

Jumlah $\longdiv { 1 6 }$

Besar nilai allowance yang didapat oleh Operator dimana pekerjanya seorang Operator wanita, maka allowance nya adalah $16+3 \%=19 \%$. Jadi waktu baku yang didapat Operator adalah:

$\mathrm{Wb}=10,52$ menit $+(0,19 \times 10,52)$

$\mathrm{Wb}=12,52$ menit

Hasil perhitungan yang telah dilakukan, maka didapat waktu standar yang diperlukan untuk menyelesaikan berbagai elemen pekerjaan dari pengamatan tersebut adalah 12,52 menit untuk satu konsumen.

\section{Simpulan}

Setelah melakukan pengamatan dan penelitian secara langsung kegiatan karywan bagian kasir Minimarket X di Kota Dumai dapat di ambil kesimpulan bahwa untuk melayani satu orang konsumen diperlukan waktu 12,52 menit. Waktu ini merupakan waktu standar seorang kasir Minimarket X setelah menerapkan faktor penyesuaian dan pemberian kelonggaran menurut Sutalaksana, dkk (2006).

\section{Daftar Pustaka}

Fitra, 2019, Pengukuran Tingkat Pemahaman Shift Kerja Perusahaan X, Buletin Utama Teknik Vol.14, No.3, Bulan Mei. 
Fitra, Mesra, T., dan Melliana, 2020, Penghitungan Waktu Baku Dengan Metode Work Sampling Pada SPBU XYZ di Kota Dumai, Buletin Utama Teknik Vol. 15, No.3, Bulan Mei.

Sutalaksana, I.Z., Anggawisastra, R., dan Tjakraatmadja, J.H., 2006, Teknik Perancangan Sistem Kerja, Penerbit ITB Bandung. 